\title{
Rapid in vitro shoot regeneration of Valeriana officinalis
}

\author{
Minoo Tansaz ${ }^{1}$, Akram Zamani ${ }^{2}$ and Mahmoud Otroshy ${ }^{*}$ \\ Department of Plant Tissue Culture, Branch of Central Region of Iran, Agricultural \\ Biotechnology Research Institute of Iran (ABRII), Isfahan, Najafabad, \\ P. O. Box 85135-487, Iran
}

Key words: Valeriana officinalis, New combined formulations medium

\begin{abstract}
A protocol for efficient and rapid regeneration of medicinal plant (Valeriana officinalis L.) was developed by in vitro culture of crown division. The effect of three different culture media, MS, B5 and MB (a new combined medium) containing 12 combinations of BAP and NAA was evaluated on regeneration and growth parameters. Results revealed a significant response of media used for shoot regeneration. The best frequency of regenerated plantlets $(80 \%)$ and number of regenerated shoots (9.43) were obtained on MB containing BAP $(0.5$ $\mathrm{mg} / \mathrm{l})+(0.25 \mathrm{mg} / \mathrm{l})$. The maximum length of shoots was found in the MB with BAP $(1 \mathrm{mg} / \mathrm{l})+(0.5 \mathrm{mg} / \mathrm{l})$. A positive influence of time was noticed on rooting of regenerated shoots. All acclimatized plantletswere successfully established in a greenhouse and showed normal growth. This protocol provides a technique for mass propagation of valerian and helpful for future genetic improvement studies.
\end{abstract}

\section{Introduction}

Valeriana officinalis L., commonly called valerian, is a perennial herb and belongs to the Valerianaceae (Wang et al. 2010). This plant is a native to Europe and Asia and has naturalized in eastern North America, which mainly grows in the northern temperate and cold regions (Abdi 2012, Zebarjadi et al. 2011, Murti et al. 2011). Valerian contains over 150 chemical constituents; many of them are physiologically active (Patocka and Jakl 2010). The roots and rhizomes of $V$. officinalis can have a wide variation in the composition of these constituents such as valerenic acids, valepotriates, baldrinal and homobaldrinal, alkaloids, amino acids such as arginine, glutamine, tyrosine, phenolic acids and flavonoids

*Author for correspondence: <otroshy@yahoo.com>. 'Department of Agricultural Biotechnology, Payam Noor University of Karaj, Karaj, Iran. ${ }^{2}$ Department of Agricultural Biotechnology, Payam Noor University of Isfahan, Isfahan, Iran. 
(Ekhteraei Tousi et al. 2010). Valerian has been used in traditional medicine for their sedative, ansiolitic, antidepressant, antihypertensive, antioxidant and antispasmodic properties. The pharmacological effects of valerian have primarily been attributed to the valepotriates (iridoid esters), ballerinas, volatile oils, monoterpenes, and sesquiterpenes constituents (Abdi 2012, Wang et al. 2010, Ansari et al. 2013).

In 1998, valerian was the tenth most popular herbal cure sold in the United States. Now, valerian extracts are available as dietary supplements, which are primarily composed of dried root or extracts from the root, formulated into tablets or soft gelatin capsules are extensively used with an estimated 210 million doses sold annually in the United States and 125 million doses sold annually in Europe (Patocka and Jakl 2010). Traditionally, valerian is mainly propagated by seeds or root divisions. Propagation through the seed and root is faced with many constraints because the seeds lose their viability after the first year and fresh seeds also have only 30 percent viability. Propagation by multiplication of roots is faced with root rot and white mold infections (Janke 2004). Nowadays, plant tissue culture techniques are being used as a powerful tool for plant propagation, particularly in clonal propagating of high-value varieties (Premkumar et al. 2001). A culture medium with an optimal mineral supply and a combination of plant growth regulators will increase the success of in vitro plant regeneration (Oliveira et al. 2010). Plant regeneration of Valeriana wallichii, $V$. edulis and $V$. jatamansi has been reported in earlier studies (Abdi 2012) but, to the best of our knowledge few information are available on clonal propagated valerian and research on the medium for in vitro regeneration of $V$. officinalis plantlet propagation is very poor. Thus, the present study examined the effects of different BAP and NAA combinations and basal media on in vitro propagation of $V$. officinalis.

\section{Materials and Methods}

The experiment was carried out during the 2013-2014 at the Plant Tissue Culture Laboratory of Agricultural Biotechnology Research Institute of Iran, to investigate the effects of different culture media formulations and various combinations of plant growth regulators on in vitro regeneration and growth parameters of $V$. officinalis.

Seeds of valerian were supplied from the seed collection of Research Center of Agriculture and Natural Resources of Iran, Isfahan in 2013. To provide clean plant materials, seeds must be sterilized and then germinated under in vitro conditions. Therefore, the seeds were washed thoroughly with running tap water for five times and subsequently disinfected (surface sterilized) by soaking 
in $0.1 \% \mathrm{HgCl}_{2}$ solution for 10 minutes, Submerging in $70 \%$ ethanol during $60 \mathrm{sec}$ and mixing with $20 \% \mathrm{NaClO}+0.05 \%$ Tween 20 during 10 min followed by several rinses with sterile distilled water to remove excess of the disinfectants. Germination of the sterilized seeds was carried out on plant growth regulatorfree MS. The cultures were incubated in a growth room at $24^{\circ} \mathrm{C}$ under a $16 \mathrm{hrs}$ light $/ 8 \mathrm{hrs}$ dark regime at $80-85 \mu \mathrm{mol} / \mathrm{m}^{2} / \mathrm{s}^{1}$ under cool white fluorescent light.

Regeneration media were based on MS, B5 and a new hybrid formulation of MS and B5 media (MB): (i) Full strength MS salts and vitamins + 3\% sucrose, $\mathrm{pH}$ 5. 8. (ii) Full strength $B 5$ (Gamborg et al. 1968) salts and vitamins $+2 \%$ sucrose, $\mathrm{pH}=5$. 5. (iii) A novel combined medium (MB) containing half (MS+B5) salts and vitamins, $10 \mathrm{ml} / 1$ Fe-EDTA (iron stock) $+2.5 \%$ sucrose, pH 5.6

When the seedlings reached a height of $5-10 \mathrm{~cm}$, their crown was excised to 2 - 3 segments bearing one bud in aseptic condition and transferred into MS, B5 and $\mathrm{MB}$ media, solidified with $0.7 \%$ agar, $0.3 \%$. The medium contained activated charcoal and various combinations of $\operatorname{BAP}(0,0.5,1$ and $1.5 \mathrm{mg} / \mathrm{l})$ and NAA (0, 0.25 and $0.5 \mathrm{mg} / \mathrm{l})$. All cultures were incubated under the same conditions as mentioned above. Transferring the shoots into the rooting medium was not needed because the shoots were rooted at the same time. The percentage of plantlet and root regeneration (number of explants with adventitious shoots and roots/total number of explants), the number of shoots per explants (number of adventitious shoots/total number of explants) and average length of the shoot were calculated for the explants after that were cultured for six weeks.

The in vitro grown plantlets with well-developed root systems were transplanted into poly pots containing peat moss, cocopeat and perlite (in a ratio of $2: 1: 1$ ) and then covered with polyethylene bag to maintain the humidity. The plantlets were acclimated under controlled greenhouse condition at $24^{\circ} \mathrm{C}$ with a 16/8 hrs (light/dark) photoperiod and irrigated regularly.

This experiment was conducted as a completely randomized factorial design with three replications and 5 explants per replication. Data were statistically analyzed, using SAS Statistical Software package (Ver. 9.1). The mean comparisons were carried out by DMRT at a probability level of $5 \%(p=0.05)$.

\section{Results and Discussion}

The effect of three different culture media containing same combinations of BAP and NAA was examined on in vitro regeneration and growth parameters of $V$. officinalis. Interaction of different culture media and PGRs combinations showed significant effect on the number of shoots per explants (Table 1).

The MB medium resulted in the best values on the percentage of regenerated plantlets and the mean number of the propagated micro- shoots (Fig. 1, a -c). A 
highest percentage of regenerated plantlet $(80 \%)$ was obtained from the interaction of $\mathrm{MB}$ medium with BAP $(0.5 \mathrm{mg} / \mathrm{l})$ in combination with NAA $(0,0.25$ and $0.5 \mathrm{mg} / \mathrm{l})$ or BAP $(1 \mathrm{mg} / \mathrm{l})$ combined with NAA (0 and $0.25 \mathrm{mg} / \mathrm{l})$ but, did not differ significantly (Table 2). In comparison, B5 medium without any PGRs or containing BAP $(1.5 \mathrm{mg} / \mathrm{l})+$ NAA $(0.5 \mathrm{mg} / \mathrm{l})$ showed the minimum effects $(40 \%)$ on regenerating plantlets (Table 2). In the present study, MB medium containing BAP $(0.5 \mathrm{mg} / \mathrm{l})+$ NAA $(0.25 \mathrm{mg} / \mathrm{l})$ showed synergistic effects producing the maximum number of micro-shoots (9.43; Fig. 1, d and e) as compared to other treatments containing higher or lower concentration of BAP and NAA. Again, the lowest value for propagating shoots (1.25) was occurring on B5 basal medium with no PGRs (Table 2). The results meant that media, various plant growth regulators or their interactions differ significantly in length of regenerated shoots (Table 1).

Table 1. Mean squares of ANOVA for the percentage of plantlet and root regeneration, the number of shoots per explants and average length of shoot of $V$. officinalis.

\begin{tabular}{lccccc}
\hline Source & df & $\begin{array}{c}\% \text { regenerated } \\
\text { plantlets }\end{array}$ & $\begin{array}{c}\text { Number } \\
\text { of shoots }\end{array}$ & $\begin{array}{c}\text { Length of } \\
\text { shoots }\end{array}$ & $\begin{array}{c}\% \text { rooted } \\
\text { plantlets }\end{array}$ \\
\hline PGRs & 35 & $0.94^{* *}$ & $9.96^{* *}$ & $12.40^{* *}$ & $399.64^{* *}$ \\
Media & 2 & $6.55^{* *}$ & $70.63^{* *}$ & $102.11^{* *}$ & $1056.97^{* *}$ \\
BAP & 3 & $0.93^{* *}$ & $7.99^{* *}$ & $6.60^{* *}$ & $394.64^{* *}$ \\
NAA & 2 & $0.18^{* *}$ & $2.03^{* *}$ & $2.53^{* *}$ & $117.37^{* *}$ \\
Media*BAP & 6 & $0.14^{* *}$ & $2.78^{* *}$ & $12.99^{* *}$ & $253.50^{* *}$ \\
Media*NAA & 4 & $0.14^{* *}$ & $9.78^{* *}$ & $6.24^{* *}$ & $420.69^{* *}$ \\
BAP*NAA & 6 & $1.12^{* *}$ & $13.67^{* *}$ & $10.28^{* *}$ & $495.89^{* *}$ \\
Media*BAP*NAA & 12 & $0.71^{* *}$ & $3.78^{* *}$ & $3.36^{* *}$ & $356.31^{* *}$ \\
Error & 72 & 0.01 & 0.15 & 0.001 & 1.42 \\
Total & 108 & & & & \\
\hline
\end{tabular}

*and ${ }^{* *}$ : significant at $\mathrm{p}=0.05$ and $\mathrm{p}=0.01$, respectively.

According to Table 2, the longest regenerated shoots $(9.35 \mathrm{~cm})$ were observed in MB culture medium supplemented with BAP $(1 \mathrm{mg} / \mathrm{l})+\mathrm{NAA}(0.25 \mathrm{mg} / \mathrm{l})$ but, are not significantly different from MS + [BAP $(1 \mathrm{mg} / \mathrm{l})+\mathrm{NAA}(0.5 \mathrm{mg} / \mathrm{l})]$. This growth parameter decreased to its lowest value when MS basal medium with no PGRs or B5 fortified with BAP $(1.5 \mathrm{mg} / \mathrm{l})+\mathrm{NAA}(0.5 \mathrm{mg} / \mathrm{l})$ were used. Analysis of the data suggested that various medium types and different concentrations of PGRs had a significant effect on the percentage of rooted plantlets (dF 12, MS 356.31, error 1.42, $\mathrm{p}=0.01$ ). 
Table 2. Interaction effects of different media and PGRs on regeneration and growth of plantlet of V. officinalis.

\begin{tabular}{|c|c|c|c|c|c|}
\hline Media & $\begin{array}{l}\text { PGRs } \\
(\mathrm{mg} / \mathrm{l})\end{array}$ & $\begin{array}{l}\text { Regenerated } \\
\text { plantlets } \\
(\%)\end{array}$ & $\begin{array}{c}\text { Number of } \\
\text { shoots }\end{array}$ & $\begin{array}{c}\text { Length of } \\
\text { shoots }\end{array}$ & $\begin{array}{c}\text { Rooted } \\
\text { plantlets } \\
(\%)\end{array}$ \\
\hline \multirow{12}{*}{ B5 } & $\mathrm{BAP}(0)+\mathrm{NAA}(0)$ & $40.00^{\mathrm{h}}$ & $1.25 \mathrm{q}$ & $2.60^{\circ}$ & $68.75 \mathrm{~g}$ \\
\hline & $\mathrm{BAP}(0)+\mathrm{NAA}(0.25)$ & $45.00 \mathrm{~g}$ & $6.18^{\mathrm{h}}$ & $4.82^{\mathrm{kl}}$ & $100^{\mathrm{a}}$ \\
\hline & $\mathrm{BAP}(0)+\mathrm{NAA}(0.5)$ & $60.00^{e}$ & $4.06^{\text {no }}$ & $4.66^{1}$ & $100^{\mathrm{a}}$ \\
\hline & $\mathrm{BAP}(0.5)+\mathrm{NAA}(0)$ & $75.00^{\mathrm{b}}$ & $4.93^{\mathrm{klm}}$ & $3.80^{\mathrm{n}}$ & $100^{a}$ \\
\hline & $\mathrm{BAP}(0.5)+\mathrm{NAA}(0.25)$ & $65.00^{\mathrm{d}}$ & $5.18^{\mathrm{jkl}}$ & $5.29 \mathrm{k}$ & $81.25^{\mathrm{d}}$ \\
\hline & $\mathrm{BAP}(0.5)+\mathrm{NAA}(0.5)$ & $70.00^{c}$ & $2.06^{\mathrm{P}}$ & $2.72^{\circ}$ & $87.50^{c}$ \\
\hline & $\mathrm{BAP}(1)+\mathrm{NAA}(0)$ & $65.00^{\mathrm{d}}$ & $5.93^{\mathrm{hi}}$ & $4.11^{\mathrm{m}}$ & $81.25^{\mathrm{d}}$ \\
\hline & $\mathrm{BAP}(1)+\mathrm{NAA}(0.25)$ & $60.00^{e}$ & $5.08^{\mathrm{fg}}$ & $6.14^{\mathrm{hi}}$ & $100^{a}$ \\
\hline & $\mathrm{BAP}(1)+\mathrm{NAA}(0.5)$ & $50.00^{f}$ & $3.43^{\circ}$ & $4.23^{\mathrm{m}}$ & $80.00^{\mathrm{d}}$ \\
\hline & $\mathrm{BAP}(1.5)+\mathrm{NAA}(0)$ & $65.00^{\mathrm{d}}$ & $4.37 \mathrm{mn}$ & $2.47 \mathrm{p}$ & $81.25^{\mathrm{d}}$ \\
\hline & BAP(1.5)+NAA(0.25) & $75.00^{\mathrm{b}}$ & $4.31 \mathrm{mn}$ & $2.75^{\circ}$ & $93.75^{b}$ \\
\hline & $\mathrm{BAP}(1.5)+\mathrm{NAA}(0.5)$ & $40.00^{\mathrm{h}}$ & $5.12^{\mathrm{jkl}}$ & $1.56 \mathrm{q}$ & $50.00^{\mathrm{h}}$ \\
\hline \multirow{12}{*}{ MS } & $\mathrm{BAP}(0)+\mathrm{NAA}(0)$ & $60.00^{\mathrm{e}}$ & $4.50^{\operatorname{lmn}}$ & $1.10^{\mathrm{q}}$ & $75.00^{\mathrm{e}}$ \\
\hline & $\mathrm{BAP}(0)+\mathrm{NAA}(0.25)$ & $60.00^{e}$ & $4.00^{\text {no }}$ & $2.41 \mathrm{p}$ & $68.75 \mathrm{~g}$ \\
\hline & $\mathrm{BAP}(0)+\mathrm{NAA}(0.5)$ & $60.00^{e}$ & $7.06^{\mathrm{ef}}$ & $6.04^{\mathrm{i}}$ & $100^{a}$ \\
\hline & $\mathrm{BAP}(0.5)+\mathrm{NAA}(0)$ & $75.00^{\mathrm{b}}$ & $7.06^{\mathrm{ef}}$ & $4.48^{\mathrm{lm}}$ & $93.75^{b}$ \\
\hline & $\mathrm{BAP}(0.5)+\mathrm{NAA}(0.25)$ & $75.00^{\mathrm{b}}$ & $5.50^{\mathrm{ijk}}$ & $3.83^{n}$ & $100^{\mathrm{a}}$ \\
\hline & $\mathrm{BAP}(0.5)+\mathrm{NAA}(0.5)$ & $70.00^{c}$ & $5.50^{\mathrm{ijk}}$ & $6.06^{\mathrm{i}}$ & $87.50^{c}$ \\
\hline & $\mathrm{BAP}(1)+\mathrm{NAA}(0)$ & $70.00^{c}$ & $5.93^{\mathrm{hi}}$ & $4.75^{1}$ & $87.5^{c}$ \\
\hline & $\mathrm{BAP}(1)+\mathrm{NAA}(0.25)$ & $75.00^{\mathrm{b}}$ & $5.62^{\mathrm{hijk}}$ & $6.90^{\mathrm{e}}$ & $75.00^{\mathrm{e}}$ \\
\hline & $\mathrm{BAP}(1)+\mathrm{NAA}(0.5)$ & $70.00^{c}$ & $4.12^{\mathrm{no}}$ & $8.81^{\mathrm{ab}}$ & $87.5^{c}$ \\
\hline & $\mathrm{BAP}(1.5)+\mathrm{NAA}(0)$ & $75.00^{\mathrm{b}}$ & $7.31^{\text {def }}$ & $4.54^{\mathrm{lm}}$ & $93.75^{b}$ \\
\hline & $\mathrm{BAP}(1.5)+\mathrm{NAA}(0.25)$ & $70.00^{c}$ & $5.75^{\mathrm{hij}}$ & $4.62^{1}$ & $87.50^{c}$ \\
\hline & $\mathrm{BAP}(1.5)+\mathrm{NAA}(0.5)$ & $70.00^{c}$ & $7.68^{\mathrm{bcd}}$ & $3.59^{\text {no }}$ & $87.50^{c}$ \\
\hline \multirow{12}{*}{ MB } & $\mathrm{BAP}(0)+\mathrm{NAA}(0)$ & $70.00^{c}$ & $4.06^{\text {no }}$ & $6.21^{\mathrm{h}}$ & $93.75^{b}$ \\
\hline & $\mathrm{BAP}(0)+\mathrm{NAA}(0.25)$ & $70.00^{c}$ & $8.12^{\mathrm{bc}}$ & $6.82^{\mathrm{f}}$ & $93.75^{b}$ \\
\hline & $\mathrm{BAP}(0)+\mathrm{NAA}(0.5)$ & $70.00^{c}$ & $7.75^{\mathrm{bcd}}$ & $6.21^{\mathrm{h}}$ & $87.50^{c}$ \\
\hline & $\mathrm{BAP}(0.5)+\mathrm{NAA}(0)$ & $80.00^{a}$ & $7.12^{\mathrm{ef}}$ & $6.96^{\mathrm{cd}}$ & $100^{\mathrm{a}}$ \\
\hline & $\mathrm{BAP}(0.5)+\mathrm{NAA}(0.25)$ & $80.00^{a}$ & $9.43^{\mathrm{a}}$ & $7.04^{c}$ & $100^{\mathrm{a}}$ \\
\hline & $\mathrm{BAP}(0.5)+\mathrm{NAA}(0.5)$ & $80.00^{a}$ & $6.25 \mathrm{gh}$ & $6.43^{\mathrm{fg}}$ & $100^{a}$ \\
\hline & $\mathrm{BAP}(1)+\mathrm{NAA}(0)$ & $80.00^{a}$ & $7.43^{\text {cdef }}$ & $7.13^{c}$ & $100^{a}$ \\
\hline & $\mathrm{BAP}(1)+\mathrm{NAA}(0.25)$ & $80.00^{a}$ & $5.31^{\mathrm{ijk}}$ & $9.35^{\mathrm{a}}$ & $93.75^{b}$ \\
\hline & $\mathrm{BAP}(1)+\mathrm{NAA}(0.5)$ & $75.00^{\mathrm{b}}$ & $7.93^{\mathrm{bcd}}$ & $8.05^{\mathrm{b}}$ & $93.75^{b}$ \\
\hline & $\mathrm{BAP}(1.5)+\mathrm{NAA}(0)$ & $70.00^{c}$ & $7.93^{\mathrm{bcd}}$ & $6.40 \mathrm{~g}$ & $93.75^{b}$ \\
\hline & BAP(1.5)+NAA(0.25) & $70.00^{c}$ & $8.56^{\mathrm{bcd}}$ & $6.41 \mathrm{~g}$ & $100^{a}$ \\
\hline & $\mathrm{BAP}(1.5)+\mathrm{NAA}(0.5)$ & $70.00^{c}$ & $8.25^{\mathrm{b}}$ & $4.94^{\mathrm{kl}}$ & $87.50^{c}$ \\
\hline
\end{tabular}

Means followed by different capital letters in columns are significantly different at $p=0.05$ according to Duncan's multiple range test.

All micro-shoots were successfully rooted in the same regeneration medium and developed long, numerous roots after 2 - 4 weeks (Fig. 1, d and e) and so it 
was not needed to transfer the explants into the rhizogenesis medium. Based on Table 2, the percentages of in vitro rooted plantlets varied from $50 \%$ for B5 + [BAP $(1.5 \mathrm{mg} / \mathrm{l})+\mathrm{NAA}(0.5 \mathrm{mg} / \mathrm{l})]$ to $100 \%$ for several treatments such as MS +NAA $(0.5 \mathrm{mg} / \mathrm{l})$ or $\mathrm{MB}+$ [BAP $(0.5 \mathrm{mg} / \mathrm{l})+\mathrm{NAA}(0.5 \mathrm{mg} / \mathrm{l})]$. All plantlets with well-developed root system were acclimated in greenhouse and showed normal growth (data were not shown, Fig. 1 f).

Medium is a key factor in plantlets propagation, strengthening and rooting (Ge and $\mathrm{Yu}$ 2005). Modified culture media such as MSB (Abdellatef and Khalafallah 2008, Klcova and Gubisova 2008) (Combination of MS salts and B5 vitamins) or Preece medium (attributed to Dr. John Preece, Southern Illinois University) based on WPM and DKW have been developed. Depend on their basal salt formulation, different in vitro responses might be occurred (Abdellatef and Khalafallah 2008). For example, B5 is probably because of their low salt content compared to MS, is suitable to the sensitivity of the species to high saltconcentrations present in MS (Droste et al. 2005). Hybrid media would occasionally be considered as superior to their original medium.
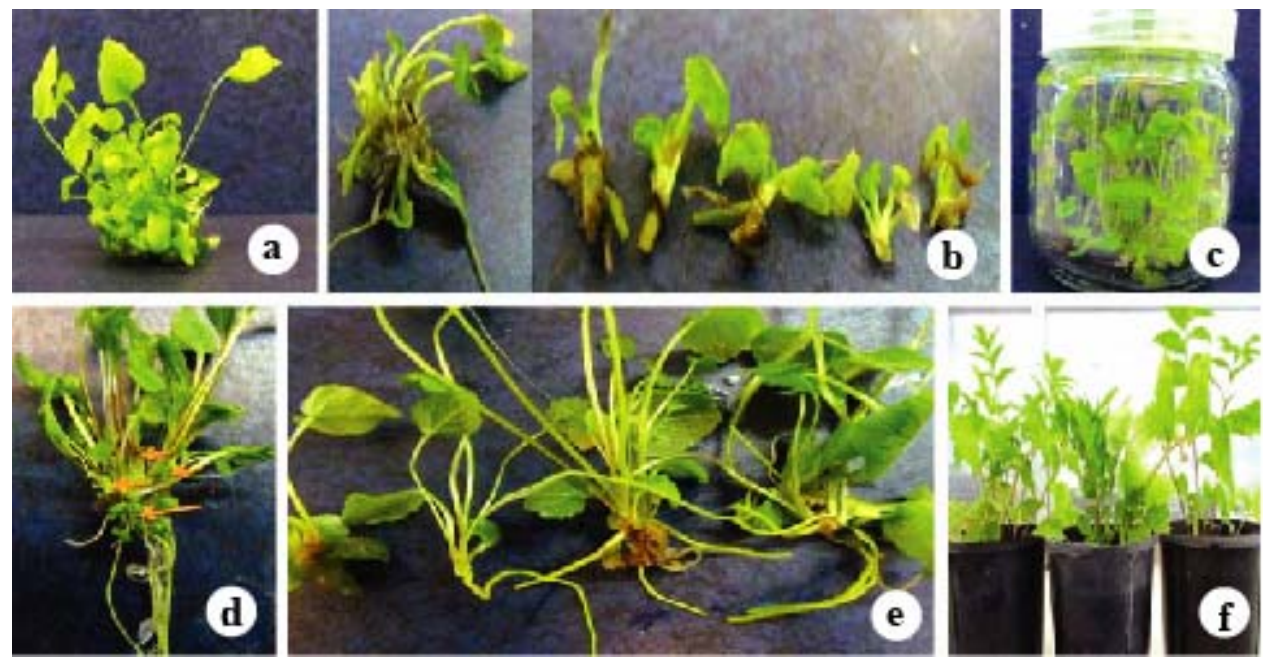

Fig. 1. Regenerated plantlets from the interaction of $\mathrm{MB}$ medium with $(0.5 \mathrm{mg} / \mathrm{l}) \mathrm{BAP}+(0.25 \mathrm{mg} / \mathrm{l})$ NAA (a); dissected micro-shoots (b); further proliferation on MB medium comprising $(0.5 \mathrm{mg} / \mathrm{l})$ $\mathrm{BAP}+(0.25 \mathrm{mg} / \mathrm{l}) \mathrm{NAA}(\mathrm{b}-\mathrm{d})$; proliferated micro-shoots with well-developed root system (e); acclimated plantlets with normal growth in the greenhouse (f).

The better results of obtaining in the MB medium as compared to MS might be caused by differences in ammonium to nitrate ratio. It is reported that the regeneration frequencies can be improved significantly by reducing the total amount of nitrogen and the ratio of $\mathrm{NH}_{4}$ to $\mathrm{NO}_{3}$ in the media (Igarashi and Yuasa 1994). The ratio of $\mathrm{NH}_{4}$ to $\mathrm{NO}_{3}$ in $\mathrm{MS}$ and $\mathrm{MB}$ media is $1.9: 1$ and $1.4: 1$, 
respectively. $\mathrm{MB}$ medium was effective for in vitro plantlet regeneration, adventitious shoot induction, plantlet height and rooting. Explants cultured in MB media stimulated more morphogenesis than the MS and B5 media. In our study, MB medium was fortified with $10 \mathrm{ml} / 1$ Fe-EDTA (2-fold of original MS or B5).

The results reported by Javad et al. (2012) also revealed that the number of shoots per explants of Stevia rebaudiana increased gradually by enhancement of the concentration of Fe-EDTA in an agitated MS up to an optimum concentration of Fe-EDTA that is, $80 \%$ of the original MS or $9 \mathrm{ml} / 1$ of the MS. The optimum phosphorous level in MB (1.25 M) or MS (1.17 M) medium might be responsible for better shoot elongation than B5 $(1.10 \mathrm{M})$. It is reported that a low supply of phosphorous may decrease levels of cytokinins in the shoots, thereby reducing protein synthesis (De Groot et al. 2003). Based on our findings, BAP was found essential for plant regeneration. Previous studies reported a maximum percentage of direct shoot regeneration, length and number of shoots of $V$. officinalis on MS medium supplemented with $1 \mathrm{mg} / \mathrm{l} \mathrm{BAP}$. A combination of $6 \mathrm{mg} / \mathrm{l}$ 2ip with $0.3 \mathrm{mg} / \mathrm{l} \mathrm{IAA}$ induced an optimal proliferation rate (Abdi and Khosh-Khui 2007) confirming our results showing that a combination of BAP and NAA was essential for maximum microshoot propagation in all media, although the balance between these PGRs for elevation of shoot induction varied among MB, MS and B5 media culture. (Luisa et al. 2002) developed a practicable method for multiplying Valeriana glechomifolia. The auxiliary buds and shoot tips were cultured in $0.3 \mu \mathrm{M}$ MS basal medium supplemented either with $0.4 \mathrm{mg}$ BAP or without plant growth regulators. The cultured segments grew on both media producing roots after 3 - 4 weeks (Abdi and Khosh-Khui 2007). Cytokinins when added with auxins promote cell division and auxins may also play a direct regulatory role in the balance of cytokinins levels by suppressing the synthesis rate and pool size of cytokinins (Ulhasan et al. 2010). The shoot numbers were significantly influenced by cytokinins and auxins combination. Since auxins can initiate cell division, they are involved in the formation of meristems, causing either unorganized tissue or well-defined organs (George et al. 2008). Sajid et al. (2006) reported that the presence of NAA in the medium had a positive effect on shoot length in the presence of BAP (Ulhasan et al. 2010). Yu et al. (2001) found that the effect of NAA is probably associated with an increased cell number. Based on the results of this study, a declining trend was observed in the shoot length as concentration of BAP and NAA increased from $1 \mathrm{mg} / \mathrm{l}$ and $0.25 \mathrm{mg} / \mathrm{l}$, respectively, suggesting that, at higher concentration, the auxin and cytokinins have an inhibitory effect on shoot elongation. Shirin et al. (2007) reported that meristematic cell divisions in potato callus were blocked at high concentration of 
NAA resulting in the death of the cells. It could be concluded from the results that a higher concentration of cytokinins and auxins shows poor interaction with salts of both the media (MB and MS) causing a decrease in the shoot length. The plantlets rooted well two weeks later on the same regeneration media and thus reduced the cost of micropropagation due to the removal of the rooting medium. These results agree with those reported in previous studies; they reported that almost all the in vitro derived shoots of $V$. officinalis were rooted $(97.1-100 \%)$ in the presence of NAA (Abdi and Khosh-Khui 2007).

The above findings suggest that the basal media and plant growth regulators together influenced the regeneration process of valerian. The simple protocol using MB medium supplemented with BAP $(0.5 \mathrm{mg} / \mathrm{l})+\mathrm{NAA}(0.25 \mathrm{mg} / \mathrm{l})$ was found superior and efficient in plant regeneration for the crown meristematic tissues, thereby shortening its traditionally growth cycle.

\section{References}

Abdellatef E and Khalafallah MM (2008) Influence of growth regulators on callus induction from hypocotyls of medium staple cotton (Gossypium hirsutum L). cultivar barac B-67. J. Soil Nature 2(1): 17-22.

Abdi Gh (2012) Evaluation of the potential of nano silver for removal of bacterial contaminants in valerian (Valeriana officinalis L.) tissue culture. J. Biol. Environ. Sci. 6(17): 199-205.

Abdi Gh and Khosh-Khui M (2007) Shoot regeneration via direct organogenesis from leaf segments of valerian (Valeriana officinalis L.). Intl. J. Agric. Res. 2(10): 877-882.

Ansari Dugaheh M, Meisami F, Torabian Z and SharifiFar F (2013). Antioxidant effect and study of bioactive components of Valeriana sisymbriifolia and Nardostachys jatamansii in comparison to Valeriana officinalis. Pak. J. Pharm. Sci. 26(1): 53-58.

De Groot CC, Marcelis FML, Boogaard RVD, Kaiser WM and Lambers H (2003). Interaction of nitrogen and phosphorus nutrition in determining growth. Plant and soil Springer Netherland 248: 257-268.

Droste A, Machado SA, Matos VA and Almeida WJ (2005) In vitro culture of Vriesea gigantean and Vriesea Philippocoburgii: two vulnerable bromeliads native to Southern Brazil. Brazilian Archive of Biological Technology 48: 717- 722.

Ekhteraei Tousi S, Radjabian T, Ebrahimzadeh H and Niknam V (2010) Enhanced production of valerenic acids and valepotriates by in vitro cultures of Valeriana officinalis L. Intl. J. Plant Prod. 4(3): 209-222.

Gamborg O L, Miller RA and Ojima K (1968). Nutrient requirements of suspension cultures of soybean root cells. Experimental Cell Res. 50: 151-158.

Ge T and Yu Y (2005). A powerful medium for strengthening and propagation of wheat regenerated plantlets. Electronic J. Biol. 1(3): 33-35.

George EF, Hall MA and DeKlerk GJ (2008) Plant Propagation by tissue culture. 3rd ed. Springer. 1: 1-504. 
Igarashi $\mathbf{Y}$ and Yuasa M (1994) Effect of $\mathrm{NH}_{4}$ and total nitrogen contents in the culture media on Shoot regeneration from calli in saffron (Crocus sativus L.). Plant Tissue Culture Letters 11: 61-64.

Janke R (2004) A Grower's Guide Family: Valerianaceae Life cycle. Publications from Kansas State University.Agricultural Experiment Station and Cooperative Extension Service. Retrieved from: http://www.ksre.ksu.edu/bookstore/pubs/MF2632.pdf

Javad S, NazSh, Ilyas S, Ali A, Aslam F and Munir N (2012). Study of the effect of physical state of medium and different concentrations of sucrose, ferric ethylenediamine- tetraacetic acid (FeEDTA) and $\mathrm{CuSO}_{4}$ in enhancing the micropropagation system of Stevia rebaudiana. J. Med. Plants Res. 6(9): 1800-1805.

Klcova L and Gubisova M (2008). Evaluation of different approaches to buckwheat (Fagopyrum esculentum Moench.) micropropagation. Czech. J. Genet. Plant Breed. 44(2): 66-72.

Luisa AS, Silva ALV, Fett-Neto AG, Poser GL and Rech SB (2002) Valeriana glechomifolia: in vitro propagation and production of valepotriates. Plant Sci. 163: 165-168.

Murti K, Kaushik M, Sangwan Y and Kaushik A (2011). Pharmacological Properties of Valeriana officinalis A Review. Pharmacology online Newsletter 3: 641-646.

Oliveira MLP, Costa MGC, Silva CV and Otoni WC (2010). Growth regulators, culture media and antibiotics in the in vitro shoot regeneration from mature tissue of citrus cultivars. Pesqagropec bras Brasília 45(7): 654-660.

Patocka J and Jakl J (2010). Biomedically relevant chemical constituents of Valeriana officinalis. J. Appl. Biomed. 8: 11-18. Doi: 10.2478/v10136-009-0002-z

Premkumar A, Mercado JA and Quesada MA (2001). Effects of in vitro tissue culture conditions and acclimatization on the contents of Rubisco, leaf soluble proteins, photosynthetic pigments, and C/N ratio. J. Plant Physiol. 158: 835-840.

Sajid GM, Ilyas MK and Anwar R (2006). Effect of diverse hormonal regimes on in vitrogrowth of grape germplasm. Pak. J. Bot. 38(2): 385-391.

Shirin F, Hossain M, Kabir ME, Roy M and Sarker SR (2007). Callus induction and plant Regeneration from internodal leaf explants of four potato cultivars. World J. Agric. Sci. 3: 1-6.

Ulhasan S Z, Ahmad T, Ahmad Hafiz I and Hussain A (2010). Direct plant regeneration from leaves of prunus rootstock GF-677 (Prunus amygdalus $\times$ P. Persica). Pak. J. Bot. 42(6): 3817-3830.

Wang J,Zhao J, Liu H, Zhou L, Liu Z, Wang J, Han J, Yu Z and Yang F (2010). Chemical analysis and biological activity of the essential oils of two valerianaceous species from China: Nardostachys chinensis and Valeriana officinalis. MDPI 15:6411-6422. Retrieved from http://www.mdpi.com/journal/molecules

Yu JQ, Li Y, Qian YR and Zhuby ZJ (2001). Cell division and cell enlargement in fruit of Lagenaria leucanthaas influenced pollination and plant growth substances. Plant Growth Reg. 33: 117-122.

Zebarjadi AR, NajafiSh, Ghasempour HR and Motamedi J (2011). Establishment of a practical tissue culture for producing hairy roots of Valeriana officinalis L. via Agrobacterium rhizogenes. J. Med. Plants Res. 5(20): 4984-4992. 